\section{La búsqueda de la identidad nacional en la novela corta mexicana (1836-1846)*}

\author{
Guadalupe \\ Gómez-Aguado \\ CEPE-UNAM
}

Quiero una imprevisible historia como lo es el curso de nuestras mortales vidas; una historia susceptible de sorpresas y accidentes, de venturas y desventuras; una historia tejida de sucesos que así como acontecieron pudieron no acontecer; una historia sin la mortaja del esencialismo y liberada de la camisa de fuerza de una supuestamente necesaria causalidad; una historia sólo inteligible con el concurso de la luz de la imaginación; una historia-arte, cercana a su prima hermana la narrativa literaria; una historia de atrevidos vuelos y siempre en vilo como nuestros amores; una historia espejo de las mudanzas, en la manera de ser del hombre, reflejo, pues, de la impronta de su libre albedrío para que en el foco de la comprensión del pasado no se opere la degradante metamorfosis del hombre en mero juguete de un destino inexorable.

Edmundo O'Gorman. ${ }^{1}$

Desde que México se independizó de España, y a lo largo de su historia como país independiente, han existido distintas interpretaciones acerca de la identidad nacional y de las características del mexicano. La identidad se ha definido como "una resultante compleja de situaciones históricas y valoraciones subjetivas". ${ }^{2}$ De ahí que en los años cruciales en que México se estrenó como país independiente se hayan tratado de plasmar en los escritos políticos e históricos esas características que identificaran a los habitantes de la nueva nación, con el fin de unir a una población por demás heterogénea bajo ideales comunes y con un pasado que perteneciera a todos. Esas ideas no sólo se plasmaron en los escritos de carácter político e histórico, sino que también se vieron reflejadas en la incipiente producción literaria de la época.

En ese sentido, las fuentes literarias no han sido utilizadas tradicionalmente por los estudiosos de la historia, y sin embargo, ofrecen un panorama que enriquece el análisis al ofrecer manifestaciones del pensamiento de la época. Estos escritos no sólo recrean escenarios de ficción, sino que reflejan en sus páginas cómo se vivieron los cambios políticos y sociales en esos primeros años de vida independiente.

\footnotetext{
* El presente artículo es una síntesis de la tesis de licenciatura de la autora: Guadalupe Cecilia, GómezAguado de Alba, "El mexicano ante sí mismo: una búsqueda de identidad a través de la novela corta (1836-1846)".

1 Edmundo O'Gorman, "Fantasmas en la narrativa historiográfica", en Historia y Grafía.

2 José del Val, México, identidad y nación, p. 15.
} 
3 John S. Brushwood, México en su novela, p. 9.

4 Miguel Othón de Mendizábal, "El origen histórico de nuestras clases medias", en Las clases sociales en México, p. 10.
El estudio de este tema a través de la literatura presenta un panorama amplio y rico, ya que la novela puede expresar la realidad de una nación por su capacidad de abarcar tanto lo visible como aquellos elementos que no se presentan a la vista. ${ }^{3}$ Aunque el novelista no pretenda específicamente reflejar la realidad o interpretarla, en toda manifestación humana - ya se trate de literatura, pintura, escultura - se pueden encontrar elementos que reflejen características de la época en que determinada obra se 11evó a cabo, y convertirlos, de alguna manera, en una fuente documental para la historia.

En cuanto a la literatura mexicana de las primeras décadas de vida independiente, ésta tuvo un desarrollo paralelo al desenvolvimiento político del país. Si México iniciaba su camino como nación civilizada, los primeros escritos nacionales buscaban mexicanizarse y ser un reflejo de la expresión de la patria recién estrenada. E1 desarrollo de la cultura en los primeros años de vida independiente, así como el análisis de algunas novelas cortas, precursoras de las letras nacionales, cuyos autores tuvieron la intención de hacer "literatura mexicana", son el tema del presente trabajo.

DE LA FORMA EN QUE SE DESARROLLARON LA SOCIEDAD Y LA CULTURA EN MÉXICO EN LAS PRIMERAS DÉCADAS DEL SIGLO XIX

Al comenzar el siglo xix la Nueva España tenía una población cercana a los seis millones de habitantes, divididos en españoles nacidos en España o peninsulares, españoles nacidos en América o criollos; indios; negros y castas. De éstos, el español y el criollo constituían el estrato superior o privilegiado y aunque según la ley tenían los mismos derechos y obligaciones, en realidad la supremacía de los españoles era absoluta a principios de la era decimonónica, lo que propició un tremendo antagonismo entre ambos grupos y, a la postre, constituiría un detonante de la guerra de independencia, ya que el descontento criollo sería cuestión fundamental entre los distintos intereses que 1levaron a la emancipación política de la Nueva España. ${ }^{4}$ 
Del total de la población, se ha calculado que de cada cien habitantes, dieciocho eran blancos, veintidós pertenecían a alguna casta y sesenta eran indios. ${ }^{5}$ Los criollos pobres ambicionaban un cambio radical que los ayudara a modificar sus condiciones de vida y a terminar con las desventajas que tenían frente a los españoles; por su parte, los indios y castas, en su mayoría, ocupaban puestos menores en la administración, la Iglesia y el ejército, o vivían en el medio rural, por lo que no tenían acceso a mayores oportunidades de progreso. Si con la independencia se quería lograr una sociedad más igualitaria, los cambios afectaron sólo a un pequeño sector de la población y la mayoría restante mantuvo en lo esencial sus costumbres y su posición en la escala social. ${ }^{6}$

La nación que se estaba gestando se enfrentaba a un panorama desolador donde la desunión, valga la paradoja, era el distintivo de los pobladores. En ese sentido, el proyecto insurgente unió la idea de nación independiente con la concepción de una "nación indígena" anterior a la conquista, lo que legitimó a los gobiernos ante los grupos nativos y le dio al nuevo país un pasado remoto alejado del mundo hispano que rechazaba; y aunque esto no terminó con las desigualdades, el mito de una "nación indígena", unió tres convicciones: "La creencia en la posibilidad de restaurar un imaginario imperio mexicano, el repudio de la dominación española y la definición de la guerra de independencia como una venganza contra las injusticias de la conquista". ${ }^{7}$ Esta visión que idealizaba el pasado indígena contra la tiranía española, se enfrentó a la de aquellos que defendían el legado hispano, lo que desembocaría más adelante en las continuas disputas ideológicas que caracterizarían los años posteriores a la consumación de la Independencia.

El catolicismo, por su parte, jugó un papel muy importante como factor de cohesión del patriotismo criollo y fue una presencia muy poderosa en la nueva nación. Esta unidad en torno a los valores de la religión católica fue el factor de mayor identificación entre los partidarios de la insurgencia, y más adelante, entre los miembros de todos los estratos sociales. ${ }^{8}$ De alguna manera, el catolicismo, como lo señalaría más adelante el historiador y político Lucas Alamán, ${ }^{9}$ era lo que mantenía unido al país a la luz
5 Josefina Zoraida Vázquez, "Los primeros tropiezos", en Historia General de México. Versión 2000, p. 560.

6 Idem.

7 Enrique Florescano, Etnia, Estado y nación, p. 334.

8 Ibid., p. 335.

9 En una carta escrita a Santa Anna el 23 de marzo de 1853 , decía “...manifestar a usted cuáles son los principios que profesamos los conservadores [...] Es lo primero conservar la religión católica, porque creemos en ella y aun cuando no la tuviéramos por divina, la consideramos como el único lazo común que liga a todos los mexicanos..." Cfr. Lucas Alamán. "Carta a Santa Anna. 23 de marzo de 1853", en Álvaro Matute. México en el siglo XIX. Antología de fuentes e interpretaciones históricas, pp. 284-286. 
10 Charles Hale, El liberalismo mexicano en la época de Mora, pp. 168-169.

11 Florescano, op. cit.., p. 363.

12 Carl Christian Sartorius, México hacia 1850, p. 118. de los problemas que se enfrentaron durante las primeras décadas de vida independiente, ya que así fueran de diferentes tendencias políticas o de distintos estratos sociales, casi todos los mexicanos eran católicos, y la tolerancia religiosa ni siquiera estaba contemplada en la Constitución. ${ }^{10}$

A pesar de que la igualdad fue uno de los ideales perseguidos por la élite ilustrada que dirigía los destinos del país, la sociedad mexicana se caracterizó por sus marcados contrastes a lo largo de todo el siglo XIX, ya que desde el nacimiento de la república, las fuerzas políticas que se disputaban el poder trataron de destruir la estructura corporativa que había dado estabilidad al país durante la época colonial, además de que no dieron cabida a las naciones indígenas en su proyecto histórico. ${ }^{11}$ Al respecto, el viajero alemán Carl Christian Sartorius decía que aunque la Constitución considerara jurídicamente iguales a todos los habitantes del país, cualquiera que fuera su color, "las costumbres profundamente arraigadas entre la gente $[. .$.$] no pueden ser eliminadas fácilmente por nin-$ guna ley", y la discriminación de que había sido objeto el indígena por parte de las clases privilegiadas iba a continuar a pesar de todo. ${ }^{12}$ Paradójicamente, la tradición indígena a la que se apelaba en los escritos históricos o en los discursos sobre la "patria" anterior a la conquista española, trató de eliminarse, así como se tuvo la intención de borrar la designación de "indio" de la vida nacional, ${ }^{13}$ con la intención de lograr la anhelada igualdad. No obstante, los descendientes de los habitantes originarios de América siguieron ahí, demostrando a las clases políticas que los problemas nacionales eran más profundos de lo que se había pensado, y que la integración de la sociedad no era una tarea fácilmente alcanzable.

Para la élite que definía los destinos de la nación, sólo sus miembros eran fiel reflejo de ésta. Lo que se quería destacar como característica propia, únicamente podía encontrarse entre los blancos, que eran una minoría ilustrada que confiaba en la aplicación irrestricta de la ley como medio para llevar al país al progreso. Si las instituciones políticas se desarrollaban conforme a estas ideas, la sociedad pronto daría testimonio de dicho avance. No se tomaba en cuenta que la mayoría de la población era de origen indígena o mestizo y vivía en un gran atraso, tanto político como social. 
En contraste, el régimen colonial había sido defensor de la tierra y la vida comunitaria de los pueblos indios y al consumarse la Independencia y triunfar la República, estas barreras protectoras se derrumbaron y con los conflictos que se suscitaron por la falta de consolidación del orden republicano, se creó un vacío político que fue ocupado por una disputa por el poder entre las élites del centro y las regionales, lo que fomentó el surgimiento de conflictos étnicos conocidos como "guerras de castas"; ello redundó en un mayor alejamiento entre las distintas capas de la sociedad, ya que para la élite rectora, dichos conflictos se convirtieron en una amenaza contra la propiedad y la civilización. ${ }^{14}$

Los problemas sociales que se vivían en la primera mitad del siglo XIX, 1levaron a los ideólogos de la época a buscar soluciones para que México saliera adelante y el progreso social fuera un hecho. Así, se pensó que las mezclas raciales serían una buena opción para "blanquear" la sociedad. ${ }^{15}$ Según Mariano Otero, en un ensayo escrito en 1842, el desorden y la miseria reinaban en el seno de la sociedad mexicana porque la propiedad estaba en quiebra, y si las clases altas eran débiles, y las clases bajas estaban reducidas a la nulidad, era en la clase media donde estaba la mayor suma de la riqueza y donde debía buscarse el carácter de la población, ya que en esa clase estaba el germen del progreso y el elemento político más favorable para la constitución de la república. ${ }^{16}$ Otero, tal como la mayoría de los ideólogos de entonces, veía en los blancos, los más favorecidos, el germen del progreso social ya que los indígenas, al igual que las castas, eran "una población abyecta y miserable", cuya mayor dificultad era el estar destinados a vivir en la miseria por la escasez de medios para satisfacer sus mínimas necesidades. ${ }^{17}$

Para los hombres públicos de la época decimonónica, la unidad nacional y el progreso social, sólo podrían conquistarse mediante la educación, ya que consideraban que por medio de ésta se formarían "hombres progresistas" que promoverían el desarrollo económico de México, además de fomentar "el orden y la moralidad en el pueblo". ${ }^{18}$
13 Hale, op. cit., p. 223.

14 Florescano, op. cit., p. 379.

15 Lucas Alamán, Historia de Méjico desde los primeros movimientos que prepararon su independencia en el año de 1808 hasta la época presente, t. V, p. 879.

16 Mariano Otero, Ensayo sobre el verdadero estado de la cuestión social y política que se agita en la República Mexicana, p. 49.

17 Ibid., p. 50.

18 Dorothy Tank de Estrada, "La educación en la nueva nación", en Historia de México Salvat, t. 9, p. 1982. 
19 Anne Staples, "Panorama educativo al comienzo de la vida independiente", en Josefina Zoraida Vázquez, et. al., Ensayos sobre historia de la educación en México, p. 119.

20 José María Luis Mora, Obras completas. Histórica 1. México y sus revoluciones, 1 , t. 4, p. 74 .
A partir de 1821, la educación en México estuvo íntimamente ligada al desenvolvimiento político del país. Todos los pensadores de la época, cualquiera que fuera su inclinación política, estaban conscientes de la necesidad de extender la enseñanza de las primeras letras a todos los rincones de la nación. La fe en la educación y, por consiguiente, el logro de una ciudadanía instruida, fue el anhelo de los grupos dirigentes. Sin embargo, la marginación de los indígenas y el abandono que sufrían los pobres de las ciudades no pudo remediarse a pesar de las buenas intenciones, cobijadas en distintos proyectos políticos. ${ }^{19}$ Entre los problemas que se enfrentaron durante las primeras décadas de vida independiente estuvieron los excesivos cambios de orden político, por lo que fue muy difícil unificar criterios para que se pudiera implantar un sistema educativo que rigiera en todo el país. Cada presidente, cada ministro de Instrucción Pública, cada rector de colegio y cada maestro tenían un sistema de estudio particular. De esta manera, los planes cambiaron constantemente, con el consiguiente descontrol que esto traía consigo.

Si bien no se logró consolidar los proyectos educativos, la intención de llevar educación a todas las capas de la sociedad por medio de libros, periódicos y revistas, se consideró como un factor indispensable para la difusión de la cultura. Con ese fin se crearon en las principales ciudades pequeños gabinetes de lectura en los que podían encontrarse novelas francesas, libros de texto, manuales técnicos, periódicos y diversos escritos de tipo religioso que eran puestos en renta para quienes querían acercarse al mundo de la letra impresa. La importación de material de lectura fue en aumento, aunque era difícil de adquirir por su alto precio. ${ }^{20}$

\section{DEL DESENVOLVIMIENTO DE LA LITERATURA MEXICANA}

En cuanto a la producción literaria posterior al movimiento de Independencia, tuvo una nueva expresión con la publicación de obras que hablaban sobre la historia de México. La necesidad de una literatura nacional que buscaba en la historia la explicación de los acontecimien- 
tos y la justificación de sus proyectos tuvo su origen en las primeras décadas de vida independiente, ${ }^{21}$ aunque la publicación de obras de los primeros representantes de las letras mexicanas no fue una tarea fácil durante el siglo XIX, ya que los creadores no tenían recursos y les era muy difícil publicar sus obras. Por esta razón, el periódico fue el vehículo de divulgación más favorable para el escritor, y las asociaciones literarias que surgieron en esa época, el medio más adecuado para satisfacer las necesidades de los primeros representantes de las letras nacionales. ${ }^{22}$ Casi todos los escritores decimonónicos tuvieron conexión con alguna asociación literaria, que eran reuniones con diversos nombres y en donde se comentaban sus obras. En dichas sociedades de carácter literario también se combinaban los intereses científicos, culturales y políticos. ${ }^{23}$

Los centros literarios no duraban mucho, pero a pesar de ello, hubo algunas asociaciones, como la Academia de Letrán y el Liceo Hidalgo, que se mantuvieron durante algunas décadas aunque con interrupciones. Del resto, muy pocas tuvieron una duración considerable. ${ }^{24}$ Los escritores que pertenecían a alguna agrupación literaria adquirían prestigio profesional e intelectual, que era aprovechado como propaganda de sus trabajos, además de ser el vehículo para obtener la aprobación de sus obras.

Fue necesario que pasaran algunos años para que surgiera la idea de buscar una independencia cultural, ya que la libertad política no fue suficiente para alcanzarla. Por mucho tiempo subsistieron reductos coloniales, y fue en la Academia de Letrán en donde se iniciaron los trabajos para lograrlo, aunque de manera paulatina. Los jóvenes escritores observaron la realidad y buscaron las bases para crear una literatura nacional. ${ }^{25}$ José Zorrilla afirmaba que esta academia fue "el verdadero punto de partida de lo que hoy puede llamarse literatura original mexicana". ${ }^{26}$

El ideal nacionalista de la Academia de Letrán coincidió felizmente con un sentimiento análogo en los grandes impresores mexicanos del siglo XIX; entre ellos Mariano Galván, Ignacio Cumplido, José Mariano Lara y Vicente García Torres, se dieron a la tarea de editar lujosas revistas, periódicos, semanarios y calendarios, en cuyas páginas dieron oportunidad de expresión a las plumas mexicanas. ${ }^{27}$
21 Julio Jiménez Rueda, Letras mexicanas en el sigloXIX, p. 103.

22 Alicia Perales Ojeda, Asociaciones literarias mexicanas. Siglo XIX, p. 16.

23 Ibid., p. 12.

24 Ibid., p. 15.

25 Ibid., p. 19.

26 José Zorrilla, La flor de los recuerdos: ofrenda que hace a los pueblos hispanoamericanos..., p. 419.

27 Jorge Ruedas de la Serna, "La novela corta de la Academia de Letrán", en Celia Miranda Cárabes, La novela corta en el primerromanticismo mexicano, p. 60. 
28 Jorge Ruedas de la Serna, "Presentación", en La misión del escritor. Ensayos mexicanos del siglo XIX, p. 8. 29 Ibid., p. 9.

30 José Luis Martínez, La expresión nacional, p. 43.
Durante el siglo XIX la actividad literaria estuvo acompañada de una amplia autorreflexión de quienes ejercieron el oficio de escritor, y sobre todo, resaltaron su utilidad e importancia para mejorar la sociedad, robustecer la opinión pública, afirmar la identidad y, con todo ello, fortalecer la conciencia nacional. Nuestros literatos decimonónicos, según expresa Jorge Ruedas de la Serna, "tuvieron clara conciencia de los valores intrínsecos de su arte y su oficio". ${ }^{28}$ En ese sentido, varios de los representantes de las letras mexicanas de entonces escribieron sobre el motivo y el sentido de la literatura. Dentro del gran proyecto civilizatorio en el que estaban comprometidos, apelaban a la creación de instituciones formadoras de nuevos artistas y estudiosos que el país requería con urgencia, y al fomento de la lectura mediante el establecimiento de escuelas, academias y bibliotecas públicas. ${ }^{29}$

Por su parte, el periodismo, una vez consumada la Independencia, tuvo un desarrollo paralelo al desenvolvimiento político del país. Surgieron publicaciones editadas por los representantes de distintas tendencias políticas, y en sus páginas convergieron los principales intelectuales mexicanos. Fue en los periódicos en donde se desarrolló una literatura paralela a la actividad pública de sus principales colaboradores; en sus páginas escribían artículos, crónicas, comentarios, cuentos, poesías y noticias. Se puede afirmar que la prensa mexicana decimonónica fue hecha por literatos.

En los periódicos editados en las primeras décadas del siglo XIX las noticias tenían un papel secundario y un espacio reducido, ya que sus páginas se dedicaban principalmente a los acontecimientos políticos, crónicas extranjeras, anuncios y documentos oficiales. En lugares preferentes aparecían poemas, cuentos, estudios históricos y científicos, artículos y cuadros de costumbres y novelas por entregas o de folletín. ${ }^{30}$ Los editores cedieron sus páginas a las noveles plumas mexicanas y con el tiempo, desterraron a los modelos extranjeros. La prensa mexicana fue expresión de las ideas de la época, y baluarte de los grupos políticos, así como medio de difusión de una literatura que pretendía ser fiel reflejo de los valores nacionales. 
La intención de reflejar la esencia de lo nacional, se manifestó tanto en las obras literarias como en las crónicas y artículos periodísticos, y de acuerdo con las ideas imperantes, España se convirtió en símbolo de todos los males, de atraso cultural y tiranía. La aspiración de realizar reformas sociales y políticas que llevaran a un orden social más avanzado y moderno también estuvo imbuida de un antihispanismo que para muchos redujo la obra de la madre patria en América a una sucesión de crímenes, codicia e ignorancia intelectual. Este sentimiento desató persecuciones políticas contra los españoles residentes en este continente, ${ }^{31}$ lo que se explica por el deseo de los habitantes de los países que habían conquistado su independencia de alejarse de los cánones peninsulares para adquirir un rostro propio.

En este sentido, al hablar de la literatura mexicana de las primeras décadas del siglo XIX, Jorge Ruedas de la Serna dice que la fase de la cultura en formación de un pueblo puede comparase con la etapa de la adolescencia en la vida humana, durante la cual para afirmarnos a nosotros mismos, nos rebelamos contra nuestros padres. "Por ello, el discurso ideológico de la literatura mexicana, durante la primera mitad del siglo XIX, se propone, sobre todo, negar el pasado colonial". ${ }^{32}$ Esta reacción es resultado, además, de las rivalidades que existían entre criollos y españoles; por su parte, el mestizo se unió al criollo en sus demandas de igualdad con respecto a los españoles, ya que sentía que al descender del conquistador y el indio, tenía aún mayores derechos sobre la propiedad de la tierra y el gobierno del país. ${ }^{33}$

Como reacción ante el rechazo a lo español y el deseo de buscar la expresión de lo nacional, durante el primer tercio del siglo xix la literatura adquirió una intensa carga ideológica que la haría participar de manera sobresaliente en el complejo proceso de creación y difusión cultural. Los intelectuales lucharon por establecer la existencia misma de la expresión literaria mexicana. Poetas, ensayistas, dramaturgos y novelistas se dieron a la tarea de cantar los esplendores de la naturaleza americana y a reproducir y explorar las peculiaridades del carácter y costumbres de sus habitantes, tal como lo proponía el movimiento romántico. ${ }^{34}$
31 Jiménez Rueda, op. cit., p. 87.

32 Jorge Ruedas de la Serna,

"Presentación", en

Historiografía de la literatura mexicana. Ensayos y comentarios, p. 9.

33 Jiménez Rueda, op. cit., p. 83.

34 Jean Franco, Historia de la literatura hispanoamericana, p. 56. En cuanto al romanticismo, este movimiento comprendía una intensa subjetividad, la búsqueda de la originalidad, la fe en el genio nacional, la huida de la ciudad y el retorno al campo, la exploración de un mundo visionario de sueños, la ruptura con las normas morales y formales, la exaltación de la espontaneidad y el entusiasmo por la libertad. En Latinoamérica, las ideas que se impusieron de un modo más rápido fueron las de la originalidad y el genio nacional, ibid., p. 95. 
35 Jiménez Rueda, op. cit., p. 96. 36 Ibid., p. 99.

37 Ibid., p. 101.

38 Tal es el caso de José Justo Gómez de la Cortina y José Joaquín Pesado, por citar algunos.

39 Cabe apuntar que durante la época colonial casi no se produjeron obras narrativas de imaginación, y las venidas del extranjero eran escasas. No hay ninguna huella de que se haya escrito y publicado una novela. Jiménez Rueda atribuye esto a lo difícil que era la publicación de libros profanos en una sociedad devota. El material de impresión era muy costoso para arriesgarse a publicar obras que iban a llegar a muy pocos lectores, además de conocer los peligros de la censura. Jiménez Rueda, op. cit., p. 108.
El romanticismo que se vivía entonces en México, no se circunscribía a una forma de expresión literaria. Según explica Julio Jiménez Rueda, se extendía a todas las actividades de la vida, era "una forma de interpretación que el hombre y la mujer del segundo tercio del siglo , le daban al fenómeno vital". ${ }^{35}$ E1 hombre romántico buscaba su felicidad y para ello tenía la pretensión de romper con las trabas que se oponían a ella. Del mismo modo, los ideólogos también buscaban la felicidad de los pueblos y modificaban las leyes que impedían lograr este ideal. Por ello coinciden con la etapa romántica una serie de revoluciones que exaltaban como dogma los derechos del hombre. En México específicamente, después del malogrado imperio de Agustín de Iturbide, se iniciaron una serie de cuartelazos que serían comunes sobre todo en la primera mitad del siglo XIX. Por lo tanto, el romanticismo, que era una manifestación del espíritu revolucionario, encajó perfectamente en la vida nacional de aquella época. ${ }^{36}$

La división que se vivía en aquel tiempo en la sociedad mexicana abarcó todos los aspectos: así el político, como el religioso, social y cultural. Jiménez Rueda dice que "nunca la sociedad mexicana ha estado más dividida que en esta época en que se plantean problemas fundamentales para la vida del pueblo", ${ }^{37}$ porque los cambios políticos, así como los enfrentamientos de las distintas corrientes de pensamiento que más adelante 1levarían a la polarización entre las distintas facciones políticas, se vieron reflejados en la producción literaria. Ahora bien, el romanticismo no se apoderó totalmente de todas las obras escritas entonces, ya que un grupo de escritores mantuvo la tradición clásica, generalmente los que habían realizado sus estudios en los seminarios y leían a los poetas de los siglos de oro españoles. ${ }^{38}$

En esos años la novela empezó a cobrar auge como un modo de reflejar las costumbres de la época, especialmente la novela histórica, que era considerada por muchos escritores como el instrumento ideal para inculcar un sentido de orgullo nacional, y así, establecer normas y crear tradiciones. En ese sentido, la independencia ofreció a los habitantes de la nueva nación un motivo de búsqueda de identidad y en muchos casos la historia fue el campo propicio para ello. ${ }^{39}$ 
Según opinan diversos estudiosos, el verdadero iniciador de la novela latinoamericana ${ }^{40}$ fue el mexicano José Joaquín Fernández de Lizardi, que en 1816 comenzó a publicar en folletos por entregas E1 Periquillo Sarniento, obra de la que salieron tres tomos. El cuarto y último no vio la luz por la censura, ya que las ideas que contenía la obra no fueron bien vistas por el gobierno colonial. ${ }^{41}$ Ésta es una novela picaresca ${ }^{42}$ según los modelos españoles, pero al mismo tiempo, una vasta descripción de la sociedad de su tiempo, es decir, una galería costumbrista. ${ }^{43}$ Apareció entonces el primer personaje con características nacionales que hizo acto de presencia en una obra de ficción. No era el pícaro español ni el indio, sino el mestizo que quería decir lo que era y lo que pensaba. La novela de Fernández de Lizardi aspira a pintar una sociedad diferente de la española. ${ }^{44}$

Se considera que el tipo de narración que inició en Hispanoamérica Fernández de Lizardi, no tuvo continuadores de valía hasta la aparición completa de E1 fistol del diablo, de Manuel Payno, en 1860. Sin embargo, la producción literaria, especialmente de las décadas de los años treinta y cuarenta, puede calificarse como "literatura de aprendizaje", ${ }^{45}$ y el deseo de novelar de muchos escritores de la época se puso de manifiesto en los relatos breves, inspirados en los ideales románticos, que, a su vez, influyeron en la novela histórica y la de costumbres. La primera se inspiraba en la época colonial o en la lucha por la independencia. Por lo que concierne a la segunda, el "color local" que tanto anhelaron los románticos, influyó en ese tipo de narraciones cuyos autores buscaron la inspiración en el campo. Sin embargo, entre esa primera manifestación de las letras nacionales y la gran obra de Manuel Payno, y a pesar de la difícil situación que se vivía en México, a partir de 1836 empezaron a aparecer novelas cortas sobre todo en periódicos y revistas literarias.

Fue precisamente en ese año cuando "cuatro individuos -Juan y José María Lacunza, Manuel Tossiat Ferrer y Guillermo Prieto - sin más auxilio que el de dios (sic), sin otro estímulo que procurar esa nueva era de una literatura del país", ${ }^{46}$ fundaron la Academia de Letrán. Se considera que este proyecto fue exitoso, ya que duró hasta la década de los cincuenta y en él convergieron talentos
40 Hay quien considera que los inicios novelísticos de México fueron con Bernardo de Balbuena y su novela El siglo de oro en las selvas de Erifile (1607), obra de corte pastoril que intercala el verso y la prosa. Por otra parte, José Luis Martínez y Ralph Warner sostienen que hay dos pronovelas: Los sirgueros de la virgen sin original pecado, obra de Francisco Bramón, publicada en 1620; y La portentosa vida de la muerte, escrita por fray Joaquín Bolaños (1792). Sin embargo, ambas obras son escritos con fines catequizantes como tantos que se publicaron durante la época colonial. Cfr., Óscar Mata, La novela corta mexicana en el siglo XIX, pp. 25-26.

41 Jefferson Rea Spell, "Prólogo", en José Joaquín Fernández de Lizardi. El Periquillo Sarniento, p. v.

42 La picaresca, género español, trataba tradicionalmente de las aventuras de personajes de condición modesta que llevan una vida parasitaria respecto a la sociedad. Por lo común la novela picaresca es una historia de degradación y arrepentimiento. Cfr. Franco, op. cit., p. 46.

43 La denominación de "costumbrismo" suele reservarse a las derivaciones latinoamericanas —que comenzaron a aparecer hacia 1840 - de los "cuadros de costumbres" que popularizó en España Ramón Mesonero Romanos una década antes, aunque el costumbrismo, modalidad del realismo español, se cultivaba profusamente en España, ya como género, desde principios del siglo XVII. Cfr. Martínez, op. cit., p. 37 44 Idem.

45 Aurelio de los Reyes, op. cit., p. 644.

46 Guillermo Prieto,Memoriasdemis tiempos. 1828a1840, p. 123. 
47 Jorge Ruedas de la Serna, "La novela corta de la Academia de Letrán", en Celia Miranda Cárabes, op. cit., p. 59.

48 Zorrilla, op. cit., p. 423.

49 Perales Ojeda, op. cit., p. 89.

50 Miranda Cárabes, op., cit., p. 39.

51 Francisco Zarco, "Discurso sobre el objeto de la literatura", en La llustración Mexicana, t. I, pp. 161-168, en Ruedas de la Serna, $L a$ misión..., p. 173.

52 El Iris fue la primera de dichas revistas. La fundó y dirigió el cubano José María de Heredia en 1826. Más adelante publicó $L a$ Miscelánea (1829) y la revista Minerva de Toluca.

53 Martínez, op. cit., p. 380. El sistema de distribución de las revistas literarias era muy común en la época: suscripciones renovables a un número determinado de entregas periódicas, usualmente dotadas de foliatura progresiva y encuadrenables en volúmenes homogéneos que, por su formato $y$ marquetación, diferían poco de los libros comunes. Cfr. Ruiz Castañeda, "Estudio preliminar", en El Recreo de las familias, p. xxxix. como Ignacio Rodríguez Galván, Fernando Calderón, José María Lafragua, Eulalio Ortega, Joaquín Navarro, Manuel Payno y Andrés Quintana Roo, quien fue designado presidente por su prestigio político y literario. ${ }^{47} \mathrm{El}$ Año Nuevo. Presente Amistoso fue el órgano de publicidad de las obras producidas por los escritores de dicha Academia, que según afirma José Zorrilla, mantuvo corresponsales en varios estados del país, lo que habla de su gran importancia como medio para difundir la literatura de la época. ${ }^{48}$

A imitación de esa asociación surgieron otras como el Liceo Hidalgo que se fundó en 1849 y tenía el propósito de continuar con la labor que había llevado a cabo la Academia de Letrán en beneficio de la cultura en México. Su influencia se extendió, con algunas interrupciones, hasta el último tercio del siglo XIX. ${ }^{49}$ La Ilustración Mexicana fue su órgano informativo; el Liceo contó entre sus primeros miembros con Francisco Granados Maldonado, Félix María Escalante, Francisco González Bocanegra, Francisco Zarco y Marcos Arróniz..$^{50}$ De esta asociación "patriótica y franca en que la inteligencia es el vínculo de unión y de amistad entre la juventud ansiosa de ser útil al país", saldría, según Zarco, una literatura propia de la que los mexicanos podrían enorgullecerse..$^{51}$

Ahora bien, en este panorama tienen una importancia fundamental las llamadas revistas literarias que llenan casi todo el siglo XIX. ${ }^{52}$ De éstas, se puede decir que significaron la oportunidad para muchos noveles escritores de darse a conocer y contar con un medio de difusión de sus incipientes obras. Además de los temas literarios, estas publicaciones incluían en sus páginas muchos otros artículos de interés, lo que las llevó a tener gran aceptación entre el público lector. Su material consistía en poesías, biografías de personalidades políticas, artículos de carácter histórico o científico y en ocasiones litografías de figurines de París o Madrid. En un principio se traducían artículos extranjeros que fueron sustituidos progresivamente por biografías y ensayos sobre temas nacionales. ${ }^{53}$

E1 Año Nuevo, ya mencionado anteriormente, contó con muchos escritores importantes que dejaron escritas entre sus páginas varias novelas cortas, entre las que 
destacan Netzula, de José María Lacunza; E1 Criollo, de José Ramón Pacheco; La hija del Oidor, La procesión y Manolito el Pisaverde, de Ignacio Rodríguez Galván; María, de Manuel Payno; E1 Inquisidor de México y E1 amor frustrado, de José Joaquín Pesado. ${ }^{54}$ Esta publicación es especialmente importante porque fue la que inauguró el primer romanticismo mexicano, y la primera dedicada totalmente a la literatura. ${ }^{55}$ Éstas y otras narraciones cortas tuvieron gran auge sobre todo entre 1835 y 1850, y se publicaron alrededor de noventa en los periódicos y revistas literarias más destacadas de la época. ${ }^{56}$

Las "novelitas", como eran 1lamadas por sus contemporáneos, fueron cultivadas con agrado por los escritores de México y recibidas con simpatía por el público a través de las publicaciones periódicas, a pesar del poco oficio de sus autores. El contenido de éstas, de carácter histórico, costumbrista, del vivir cotidiano, y de énfasis sentimental, así como, ocasionalmente, de tema indígena, son una fuente documental para el conocimiento de la evolución literaria mexicana a partir de su independencia. ${ }^{57} \mathrm{No}$ es gratuito que varias de las primeras obras de ficción escritas en México hayan tenido como tema el pasado, ya que esto denota el interés por exaltar un pretérito glorioso y así, dar sustento al presente. De esta manera, según John Brushwood, "la novela de la primera mitad del siglo xix no es sólo un buen reflejo de la nación, sino que es la conciencia que está tratando de señalar el camino al sentido común y a la visión de la Independencia". ${ }^{58}$

\section{DE LA IDENTIDAD NACIONAL EN LA NOVELA CORTA}

Las novelas cortas que se analizan en este artículo son diez, escritas entre 1836 y 1846, y son una muestra de la búsqueda de una expresión literaria propia. En todos los autores se puede apreciar el deseo de plasmar costumbres, paisajes y características de la nueva nación. En este tenor, hay temas recurrentes en los relatos que son representativos de las ideas de la época, como la situación política y social imperante en el México de entonces y el rescate del pasado histórico. ${ }^{59}$ Las novelas cortas son: Manolito el pi-
54 Miranda Cárabes, op. cit., pp. 43-44.

55 Ruiz Castañeda, op. cit., p. xxi.

56 Mata, op. cit., p. 30.

57 Miranda Cárabes, op. cit., p. 51.

58 Brushwood, op. cit., p. 170.

59 En la selección de estas obras y su clasificación como novelas cortas, sigo los cánones de las características que ofrecen en sus obras Celia Miranda Cárabes y Óscar Mata que las califican como tales, y explican los motivos para ello. Vid. Cárabes, "Estudio preliminar", en La novela corta..., pp. 7-51 y Mata, "Hacia la definición de la novela corta", en ibid., pp. 11-22. 
60 Como Mi paisano apareció en El Recreo de las Familias con la firma F.C., no se tiene la certeza de quién es el autor de la obra. Celia Miranda Cárabes la atribuye a Francisco Campero, pero en María del Carmen Ruiz Castañeda y Sergio Márquez Acevedo, Diccionario de seudónimos, anagramas, iniciales y otros alias usados por escritores mexicanos y extranjeros que han publicado en México, se atribuye también la posible autoría de este relato a Fernando Calderón. (Vid. p. 145) En adelante, al referirme al autor de esta novela corta pongo las iniciales: F.C. Para ampliar la información sobre los autores de las novelas cortas mencionados en este trabajo. Vid. Gómez-Aguado, op. cit., pp. 58-64.

61 Isaiah Berlin, Las raíces del romanticismo, p. 126. Ernest Gellner, por su parte, sostiene que dos hombres son de una misma nación si comparten la misma cultura, es decir, un mismo sistema de ideas y signos, de pautas de conducta y comunicación. Además, nos dice Gellner, dos hombres son de la misma nación si se reconocen como pertenecientes a ésta. Ernest Gellner, Naciones y nacionalismo, p. 20.

62 Elsa Muñiz García, “Identidad y cultura en México", en Identidades y nacionalismos: una perspectiva interdisciplinaria, p. 24. saverde (1838), de Ignacio Rodríguez Galván; Netzula (1837), de José María Lacunza; Aventura de un veterano (1843), de Manuel Payno; Manuelita (1843), de Guillermo Prieto; El criollo (1838), de José Ramón Pacheco; El inquisidor de México (1838), de José Joaquín Pesado; Margarita (1844), de Juan N. Navarro; Una pasión (1844), de Domingo Revilla; La condesa de Peña Aranda (1844), de Ramón Isaac Alcaraz, y Mi paisano (1838), de Fernando Calderón o Francisco Campero. ${ }^{60}$

Estas obras se inscriben dentro del movimiento romántico que comenzó a cobrar auge en México durante las primeras décadas del siglo XIX. Parte importante del romanticismo como movimiento literario fue la exaltación del nacionalismo, ya que el ser humano como tal pertenecía a una sociedad con ciertos valores y tradiciones, y con características comunes que lo hacían formar parte de una nación. ${ }^{61}$ Por su parte, el nacionalismo o la identidad nacional implica una búsqueda de significados comunes que identifiquen a todos los grupos sociales contenidos en el interior de un espacio sociocultural llamado nación. Dichos grupos se constituyen en hegemónicos a medida que conforman un proyecto económico, político e ideológico suficientemente amplio para incorporar al conjunto de los habitantes de un país. ${ }^{62}$

De esta manera, la búsqueda de "lo nacional", entendido como "lo mexicano", se llevó a cabo a partir de la consumación de la Independencia, cuando un proyecto político común trató de encontrar la identificación de los habitantes de la nación con elementos que fueran afines a todos. En ese sentido, la literatura no podía ser ajena a ese anhelo de expresión nacional, como ya se ha mencionado antes, por lo que los noveles escritores plasmaron en sus obras su idea de lo que era más representativo de su país, y por lo tanto, lo que servía como medio de identificación de sus valores y características propias.

Situación política y aspectos sociales en México

Las novelas cortas motivo del presente trabajo están situadas en distintas épocas de la historia de México, pero en la mayoría de ellas los autores hicieron referencias al 
ambiente político que se vivía en el momento de escribir sus relatos. Casi todos los autores fueron muy críticos de su realidad y las dificultades en el ámbito público que se vivían en la época se dejan ver a través de las páginas de sus narraciones, lo que es un indicio de la fuerza que cobró la cuestión pública una vez que México se convirtió en nación independiente. Por otra parte, también se destacan ciertas características de la sociedad mexicana de la primera mitad del siglo XIX.

En Mi paisano ${ }^{63}$ el protagonista es un joven que acaba de regresar de París y a quien todo lo que ve en México le parece mal en comparación con lo que ha visto en Europa. El autor se dice que los lectores seguramente estarán pensando: "Este hombre sigue la rutina de todos los de este tiempo: hablar siempre de países extraños, parece que tienen a mengua el mentar siquiera a su nación; como si no hubiera que decir de México, como si nuestras costumbres, nuestra naturaleza y nuestro cielo no fueran dignos de sus plumas, como si..." ${ }^{64} \mathrm{El}$ autor de la novelita, ya sea Fernando Calderón o Francisco Campero, hace alusión a la costumbre de la época de exaltar lo extranjero frente a lo nacional, y lo presenta con un tono crítico, ya que México era digno de ponerse a la altura de cualquier nación civilizada. Como es evidente, la intención de mexicanizar la literatura, como querían los integrantes de la Academia de Letrán, se encuentra presente en este y otros relatos. Este esfuerzo nacionalista, "si por nacionalismo entendemos la supeditación de la voluntad colectiva, y por ende la individual, a un ente superior 1lamado patria", ${ }^{65}$ se deja ver en el párrafo antes citado.

De una ida al teatro, diversión común de la época para las clases acomodadas, el autor de Mi paisano dice:

El teatro principal es una gran tertulia, a donde se va por tono y no por gozar del espectáculo; por consiguiente la etiqueta exige entrar lo más tarde que se pueda, y ojalá se quedaran en sus casas, para no molestar con su habladero a los pobres que van allí para disfrutar de la música, o para gozar del maravilloso encanto de un buen drama. Una parte de los asistentes comienza por indagar la vida y milagros de la parte pacífica; luego que levantan el telón, se siguen con los cómicos, conforme van saliendo a las tablas, y concluyen por despedazarse a sí mismos. ${ }^{66}$
63 Fernando Calderón o Francisco Campero, "Mi paisano", en El Recreo de las Familias, 1838, pp. 371-384, 407-415.

64 Ibid., p. 372

65 Aurelio de los Reyes, "Manuel Payno: el aprendizaje del oficio de escritor", en Laura Suárez de la Torre (coord.), Empresa y cultura en tinta y papel (1800-1860), p. 640.

66 F.C., op. cit., p. 412. 
67 Florencio Ma. del Castillo, "Amor y desgracia", en Obras de don Florencio M. del Castillo. Novelas cortas, p. 37.

68 Ignacio Rodríguez Galván, Manolito el pisaverde, p. 191.
El autor del relato mencionado también es mordaz en cuanto a la crítica que hace a la gente que va al teatro únicamente por quedar bien, sin ningún interés en la obra en cuestión. Esta queja de los escritores se presenta también en Florencio Ma. Del Castillo, que aunque publica sus novelas en fechas posteriores a las tratadas en el presente trabajo, en este caso en 1849, coincide con el señalamiento anterior al decir:

Jamás ha tenido el público de México un gusto decidido por la literatura dramática: de un carácter frívolo, inconstante, sin duda porque nuestro pueblo, como dicen los "políticos" está todavía en mantillas [...] Sin embargo la clase alta protege indirectamente al teatro, mas tan solo por lujo; pues es para ella igual que las piezas que se presentan sean buenas o pésimas, lo que generalmente no sabe distinguir. ${ }^{67}$

Como se puede apreciar, hay un reproche implícito hacia un público que, según nuestros escritores, no entiende las obras presentadas, ya que debe madurar tanto como la literatura, que está en vías de creación. Es interesante resaltar cómo se critica a la sociedad en situaciones por demás comunes, pero que reflejan la intención del autor de mostrar una realidad que duele y un compromiso de señalar errores para mejorar.

En otra novelita, en este caso la de Ignacio Rodríguez Galván, el protagonista Manolito hace saber a Teodora que su esposo ya estaba casado con otra, pero le dice que no tiene caso que descubra el secreto ya que

si hubiera justicia en México, don Jacinto iría a un presidio. ¿Y qué conseguía usted con esto? Que en el teatro, en los paseos, en las tertulias, en un balcón, en cualquiera parte sería usted señalada, y al verla todo el mundo gritaría: "Esa es la mujer del presidiario." Pero en México no castigarán a ese hombre, y usted tendría que separarse de él por la buena opinión ante el público, y sin embargo, el honor de usted quedaría mancillado; sería usted el asunto de las conversaciones y el objeto de los tiros de la maledicencia. Aunque soy joven, tengo alguna experiencia, señora, y sé que en la edad en que vivimos se ensalza el crimen y se desprecia la virtud. ${ }^{68}$

La sociedad de la época, según los personajes de Rodríguez Galván, se regía por la maledicencia, sin siquiera 
tratar de ver la realidad. Además, el relato se aprovecha para lanzar una dura crítica a la impartición de justicia en México, en donde no se castigaba al culpable y a cambio se fomentaba el delito.

Si seguimos el mismo orden de ideas, en Margarita ${ }^{69}$ la protagonista desobedece las órdenes de su padre de casarse con don Carlos, y se fuga con Pablo, el cual tiene asegurada su fortuna porque consigue un empleo en la aduana de Mazatlán. Sin embargo, pierde el trabajo por exceso de ambición, y se hace la siguiente reflexión:

Todo se ha perdido, decía, ningún recurso me queda aquí para subsistir, es indispensable volver a México; allí con empeños... mas ¿por qué ha caído sobre mí esta desgracia, cuando otros de peor conducta que yo se mantienen en sus empleos y jamás son castigados? Mas ¡qué dudo! ¡imprudente! Haberme desavenido con ese comerciante rico, debía perderme; me cegó la codicia. ¡Si me hubiese contentado con el dinero que me ofrecía por el contrabando!... y lo peor es que nada tengo, porque el maldito juego... ${ }^{70}$

La corrupción se nos presenta como un hecho cotidiano en la vida decimonónica, y resulta que, según Navarro, hay muchos que aunque actúen mal, conservan su empleo y roban cuanto quieren. En este caso, lo importante es resaltar la crítica que el autor hace a una sociedad corrupta y deshonesta, ya que Pablo, finalmente, pierde todo por el vicio del juego y por querer pasarse de listo, nunca por haber caído en manos de la justicia.

En cuanto a las alusiones a la situación política, encontramos varias menciones de los constantes levantamientos que caracterizaban la época, y en muchos casos se nota el hastío por los problemas políticos que se vivían entonces. En Mi paisano se nos describe la actividad de un conspirador que disponía un plan de ataque:

Entre tanto un conspirador que estaba en su cuarto disponiendo su plan de ataque (y precisamente escribía entusiasmadísimo estas filantrópicas palabras: "Se incendiará la ciudad y se pasarán a cuchillo todos sus habitantes, sin exceptuar a las mujeres, a los ancianos ni a los niños; y en medio de la confusión, del estrépito y del tumulto, cada uno saqueará lo que pueda; que la verdadera libertad consiste en robar al prójimo para vivir con opulencia y holganza" ) [...] En la iglesia de San Agustín y de la Profesa tocan a
69 Juan N. Navarro, "Margarita", en El Liceo Mexicano..., t. II, pp. 181-185. 
70 Ibid., t. II, p. 184.

71 F.C., op. cit., p. 381.

72 Guillermo Prieto,

"Manuelita", en EI Siglo XIX,

1843, p. 2.

73 José Ramón Pacheco,

"El criollo", en El Año

Nuevo. Presente amistoso,

1838, t. II, pp. 208-215.

74 Ibid., p. 210. fuego, y poco después se presentan porción de soldados con muchos hombres que traían bombas, barretas, palas, azadones, y demás utensilios. (Entre paréntesis diré que en México pocas veces acuden con la misma puntualidad. $)^{71}$

El autor de esta novela corta describe lo anterior con un tono jocoso y divertido, y parece que se burla de las insurrecciones constantes, así como de los soldados que nunca responden a los llamados de auxilio con la celeridad que sería de desear, y cómo no encontrar en los levantamientos un motivo de inspiración, si éstos estaban tan presentes en la vida de los mexicanos. En el mismo tono, Guillermo Prieto describe así el cuarto del narrador de su novela, escrita en primera persona: "Hasta doce sillas, que por lo enteleridas podrían creerse viudas de militares; hasta un par de cuadros, que por lo discordantes se podrían tomar por la representación del Gobierno y del Congreso que cayó; una mesa tan mal parada como la hacienda pública..." ${ }^{72} \mathrm{El}$ autor no sólo hace una mofa del gobierno y del congreso, sino que también se burla de las viudas de los militares y del estado de la hacienda. En un corto párrafo logra describir lo que para él era el gobierno mexicano de entonces: anarquía y caos.

En un tono más serio, pero también crítico, José Ramón Pacheco compara la situación imperante en la Nueva España a principios de siglo con lo que sucedía en la época que el autor escribe El criollo: ${ }^{73}$

Todavía a principios de este siglo, y antes de que una revolución de ideas hiciese una revolución social, confundiendo todas las clases y el mérito con la inepcia, hacía la injusticia por medio del sistema colonial lo que en épocas posteriores ha hecho por medio de los partidos políticos. Así como en ellos es una mancha tener esta o aquella fe para no encontrar cuartel en el partido reinante, y esto solo explica la exclusión del mérito y la repetida e inconcebible exaltación de las nulidades, así entonces era una positiva desgracia para los mexicanos ser hijos de su hermoso suelo. ${ }^{74}$

En la cita anterior podemos ver que Pacheco está muy descontento con el resultado de la "revolución social" que no había rendido los frutos que se esperaban en la época que nuestro autor escribe. La ineptitud de los que ocupaban puestos públicos y la exclusión de los elementos 
valiosos por motivos de diferencias ideológicas constituían un problema grave en la cuarta década del siglo XIX, según el autor de El criollo, y aunque su relato se ubica a principios de siglo, no puede evitar hacer una comparación entre el pasado y el presente, de lo que resulta que las cosas seguían igual que antes y nada había cambiado.

En Una pasión, de Domingo Revilla, ${ }^{75}$ el protagonista, Diego, a quien su amada no le hace ningún caso ni quiere saber nada de él, decide unirse a un levantamiento por despecho, ya que no tiene esperanzas de que su amor sea correspondido. Nuevamente encontramos un personaje dispuesto a participar en un levantamiento no por convicción, sino como respuesta a una situación personal amorosa y no política, lo que refleja a una gran mayoría de mexicanos que como él, se unían a los pronunciamientos. Además, hay una abierta crítica a los partidos y a la situación política imperante:

Una mañana, el criado de Diego le anunció con la mayor sorpresa que había un pronunciamiento, y que el Palacio y otros puntos estaban ocupados por los sublevados. Amigo entusiasta de la verdadera libertad, odiaba los partidos, que todo lo proclaman a la vez para el engrandecimiento de algunos, y para encubrir sus miras ambiciosas, prostituyendo en su lucha la causa más sagrada del mundo: esto le hacía no ver con buen aspecto la revolución... ${ }^{76}$

El autor describe el levantamiento de 1840 ocurrido en la ciudad de México, ${ }^{77} \mathrm{y}$ dice:

E1 fuego era terrible; una lluvia de balas cubría las calles de la Monterilla, que permanecían iluminadas por mucho tiempo con el fogonazo de los fusiles y el de las piezas de la trinchera. Se presentaba la escena más espantosa, y entre los gritos de desesperación de los combatientes, y los clamores de los heridos, se oía el estruendo de las armas que despedían la muerte por todas partes: reinaban el espanto y la desolación, y los que habitaban las casas, cuyas calles eran el teatro de la guerra y carnicería, estaban en el mayor tormento. ${ }^{78}$

Revilla describe las escenas que seguramente vivió, 1o que nos permite entender su hartazgo frente a los conflictos de partidos que mantenían en constante zozobra a los habitantes de México. Lo importante en este caso es destacar que aunque se trata de una novela romántica, su
75 Domingo Revilla, "Una Pasión", en El Museo Mexicano, o miscelánea pintoresca de amenidades curiosas e instructivas. Miscuit utile dulci. Horat, 1843, t. IV, pp. 325-337.

76 Ibid., p. 334.

77 El 15 de julio de 1840 hubo un pronunciamiento en la capital del país, acaudillado por Urrea y Gómez Farías, a favor del sistema federal. Los sublevados sorprendieron al general Bustamante en el palacio de Gobierno. El presidente escapó de sus enemigos e instaló el gobierno en el convento de San Agustín. Los federalistas se fortificaron en el palacio, sede del gobierno, durante quince dias, hasta que se rindieron. Cfr. Francisco de Paula Arrangoiz. México desde 1808 hasta 1867, 1994, p. 376.

78 Revilla, op. cit., p. 336. 
79 El autor se preocupó por anotar en su narración los hechos ocurridos en ese levantamiento, basándose en la noticia de lo ocurrido aparecida en el Boletín Oficial del gobierno.

80 Alejandro González Acosta. El enigma de Jicotencal. Estudio de dos novelas sobre el héroe de Tlaxcala, 1997, p. 22.

81 Según afirma John Brushwood, no es sorprendente que las primeras obras de ficción, consumada la independencia, se interesaran en el pasado de México. El foco de atención no estuvo en ningún punto del pasado en particular, pues México "carecía de una Edad Media a la que pudieran retroceder los novelistas, como hicieron los europeos". Los temas más socorridos son los de la Inquisición, el indio idealizado en contraste con el conquistador y la defensa del criollo. Cfr. Brushwood, op. cit., pp. 154-155. autor ambienta el relato con acontecimientos que sí ocurrieron, y describe claramente la situación de la época. ${ }^{79}$

Si se hace un recuento de lo que puede verse en las novelas en cuanto a la situación política y al estado de la sociedad de la época, según lo que dicen sus autores, se podrá ver que destaca el rechazo a todo lo que está relacionado con partidos políticos y su actuación: se les relaciona con la ineptitud y se les culpa de los problemas del país. Por otra parte, los pronunciamientos, tan comunes en la época, también son motivo de crítica para los autores de algunas novelas. De igual manera, se menciona la corrupción imperante, la mala impartición de justicia y el atraso de los mexicanos en cuanto a la cultura y el arte, resultado de la propia situación política del país, cuyos dirigentes al parecer estaban más preocupados por crear conflictos que por ofrecer soluciones.

Como se puede ver, las novelas cortas resultan una fuente de información de distintos episodios de la situación política nacional, y es de destacar el interés de sus autores por rescatar el México de su momento. Más que inspirarse románticamente en su pasado, reflejaron su ambiente político y a través de un elemento literario ejercieron una crítica que traspasó su mero entorno, pues en el teatro o mediante la difusión de sus obras tuvieron un alcance mayor que el que hubieran logrado a título personal.

\section{Recreación del pasado histórico}

En cuanto a las novelitas de corte histórico, para que puedan pertenecer a ese género es necesario que haya un distanciamiento prolongado entre la época de quien escribe y la que forma el ambiente de su obra para que pueda considerarse como tal. ${ }^{80}$ Esto supone una tarea ardua para el creador, que debe llevar a cabo una labor de investigación y reconstruir el pasado aun cuando se tengan pocos indicios de lo ocurrido en épocas lejanas.

De las diez novelas cortas analizadas, cinco pueden considerarse novelas históricas, porque recrean el pasado remoto. ${ }^{81}$ En el caso de Netzula, la acción ocurre en los días previos a la conquista española; El inquisidor de México está ubicada en el siglo XVII, y Aventura de un ve- 
terano, La condesa de Peña Aranda y El criollo se ubican en los primeros años del siglo XIX, es decir, las postrimerías del régimen colonial.

La primera novela mencionada, Netzula, de José Ma. Lacunza, ${ }^{82}$ es un intento de revivir el México anterior a la conquista, y aunque no se logra, e incluso su relato podría ubicarse en cualquier periodo - ya que la ubicación temporal no está bien representada - es destacable que el glorioso pasado indígena, en contraposición a la barbarie española, sea el marco de la narración. Esta novela puede considerarse como precursora porque fue la primera narración mexicana de tema histórico, de personajes indígenas y de tratamiento romántico, lo que le da un valor importante entre las novelas cortas que se escribieron en el siglo XIX. ${ }^{83}$

Lacunza describe en su obra un mundo indígena idílico, 1leno de valores como el honor, al amor a la patria, 1a lucha por conservar lo propio y la injusticia de los conquistadores que destruyen el entorno que existía antes de su 1legada. Así empieza la novela: "Eran los últimos días de Moctezuma: el imperio volaba a su ruina, y la espada de los españoles hacía estremecer el trono del monarca; donde quiera se escuchaban sus victorias, y los hijos de América doblaban el cuello a la cadena de los conquistadores". ${ }^{84}$

En este relato hay muchos elementos que hablan del afán decimonónico de buscar en los hechos remotos sucesos de gloria en los cuales basar una historia propia, que no tuviera nada que ver con el pasado de dominación del que habían logrado emanciparse. De ahí que en Netzula los españoles sean los villanos, que van a despojar a los "héroes de América" de su patria:

El extranjero se presentó sobre las montañas: los fuertes de América estaban sobre el valle firmes, inmóviles, apoyados sobre sus ramas, como la encina, cuyas ramas se asientan en su ancho tronco; el sol estaba en sus armas; los hijos del océano se adelantan hacia nosotros, y un torrente de fuego va delante de ellos; el humo los envuelve, y el sol se oculta en un velo de nubes y sangre: el campo es todo un lago rojo, un sepulcro de héroes. ${ }^{85}$

En esta narración, el autor no menciona un lugar específico en donde ocurren los sucesos, sino que habla de "Amé-
82 José María Lacunza, "Netzula", en El Año Nuevo. Presente Amistoso, t. I, pp. $15-52$.

83 Ángel Muñoz Fernández. Los muchachos de Letrán. José María Lacunza. Estudio y recopilación, p. 95. Existe otra narración histórica de tema indígena, Jicoténcal, publicada en 1826 en Filadelfia, y de posible autoría de José María Heredia, lo que trata de probar Alejandro González Acosta, op. cit. De cualquier manera, esto no le quita a Netzula su carácter precursor, ya que es la primera narración de tema indígena escrita $y$ publicada en México, y hecha por un mexicano.

84 Lacunza, op. cit., p. 15. 85 Ibid., p. 22. 
86 Thimothy Anna, Forging México. 1821-1835, p. 7. 87 Lacunza, op. cit., p. 48. 88 Juan A. Ortega y Medina, "La primera polémica mexicana acerca de la historia", en Polémicas y ensayos mexicanos en torno a la historia, pp. 7677. rica" o "el Anáhuac", como la patria conquistada, y le da al mundo indígena una uniformidad que no tenía en realidad. Sin embargo, cabe destacar esta imagen de América como la patria común de sus habitantes, idea que prevalece en los primeros insurgentes de las antiguas posesiones españolas. En el caso específico de México, los fundadores de la independencia definieron su nación como una vieja entidad, Anáhuac, y el acta de Independencia se refiere a que se recobró el ejercicio de la soberanía usurpada. El hecho es que la nación como una realidad fue algo que los caudillos independentistas sabían que estaba en el futuro, pero a la que apelaron como si fuera un hecho. ${ }^{86}$ Vemos que Lacunza retoma esta idea en su novela, y da la imagen del mundo indígena como una totalidad que existía como tal desde antes de la conquista.

Por otra parte, los españoles no poseen una identidad determinada, es decir, no tienen nombre ni se les describe físicamente, únicamente son los conquistadores. Netzula cae en sus manos y se siente perdida: "Ha salido ya de la montaña, y repentinamente se encuentra rodeada por cuatro soldados cuya lengua es ignorada de ella: no puede dudarlo, ha caído en manos de los españoles: conoce todo el horror de su desgracia, y se resigna al sufrimiento: todo lo ha perdido para siempre: sus padres, su patria y aun su amante". ${ }^{87}$

La novela de Lacunza, sin ser una recreación histórica rigurosa, presenta en sus páginas la visión de su época acerca del significado de la conquista y es retrato fiel de la búsqueda de los mexicanos de un pasado remoto que le diera sustento a su presente. Era necesario, para tener una patria propia y un sentido de pertenencia a ella, que hubiera un pasado glorioso del cual enorgullecerse. Cabe destacar que, más adelante, cuando Lacunza estuvo al frente de la recién creada cátedra de Historia en la Academia de San Juan de Letrán, en 1843, publicó un discurso histórico en el que no mencionó en ningún momento al mundo prehispánico como un tema de estudio que debía seguirse en México. Al respecto, Ortega y Medina dice que la actitud de Lacunza revela un europeísmo entusiasta que desdeña lo propio, y aunque es y se sabe nacido en México, se siente más mexicano por sus raíces europeas que por las indígenas. ${ }^{88}$ No obstante, es evidente que en 
los años que escribió su novelita estaba muy influenciado por las ideas de mexicanizar la literatura, de ahí que el tema elegido haya sido sobre el pasado indígena, aquello que singularizaba la experiencia mexicana.

En el caso de El inquisidor de México, de José Joaquín Pesado, ${ }^{89}$ el tema, como su título lo indica, es el auto de fe seguido por el tribunal de la Inquisición contra dos jóvenes enamorados, acusados de judaizantes. ${ }^{90}$ La historia se ubica en el año de 1648 y su autor logra recrear muy bien el ambiente colonial, tanto en Jacomulco como en la ciudad de México, en donde se lleva a cabo dicho auto de fe. Además, Pesado nos presenta la figura del inquisidor Domingo Ruiz de Guevara, quien

persiguió infatigablemente a los pocos herejes, moriscos y judíos que pudo haber a las manos en estas tierras, y su rigor era tal que pasaba en proverbio. Siempre tenía en la mano la espada de Elías y nunca el bálsamo del samaritano. Es verdad que su rigor procedía de su misma rectitud; pero nadie pondrá en duda que esta misma rectitud llevada al exceso, causa tantos males como los vicios. ${ }^{91}$

Este personaje es el más importante dentro de la novela, y el autor lo presenta como un hombre celoso de su deber, honesto y rígido, quien se transforma al final por la fuerza del amor filial, ya que la judaizante condenada a la hoguera resulta ser su hija, a quien habían arrebatado de su lado cuando era muy pequeña. El padre rescata a Sara de las llamas de la hoguera, y su desesperación es tal, que se arroja a las brasas "para desatar él mismo a su hija o perecer con ella". ${ }^{92}$ El trasfondo de esta narración es una crítica al tribunal de la Inquisición, causante de males y desgracias, así como injusticias sin fin. El prometido de Sara, Jacobo Ribeiro, habla así: "porque en un país, donde existe un tribunal, que avasalla las conciencias, y se engrandece con las riquezas de los que llama sus enemigos, es imposible que éstos vivan seguros. Sobran espías y delatores..." ${ }^{93}$

Como ya se mencionó, es a partir de la culminación de la Independencia que el antihispanismo se manifiesta plenamente en México, ya que todo lo relacionado con la madre patria suena a tiranía y atraso. De ahí que surjan obras que se dedican a criticar los males prevalecientes en el régimen colonial, uno de ellos, y tal vez el más denostado, el tribunal
89 José Joaquín Pesado, "El inquisidor de México", en El Año Nuevo... t. II, pp. 99-137. Otras obras de José Joaquín Pesado son: El amor frustrado y Poesias originales y traducidas. Vid. Ruiz Castañeda, Diccionario de sinónimos..., p. 635.

90 Esta narración, junto con otras de igual extensión, o menos formales, es la precursora de las novelas sobre el mismo tema que tendrían como representantes más importantes a Justo Sierra O'Reilly con La hija del judio y a Vicente Riva Palacio con varias de sus obras. Vid. J. Lloyd Read. The mexican historical novel. 1826-1910, p. 73.

91 Pesado, op. cit., p. 102.

92 Ibid., p. 135.

93 Ibid., p. 100. 
94 Pacheco, op. cit., p. 230. 95 Ibid., p. 247. de la Inquisición. De este modo, la narración de Pesado se inserta en este camino, aunque es justo decir que trata de dar un rostro humano a la acción del inquisidor, y de entender los motivos que lo llevan a actuar como lo hace, ya que su catolicismo lo lleva a justificar a la Iglesia a pesar de los errores inquisitoriales.

Otra novelita histórica es E1 criollo. Como su nombre lo indica, el protagonista es un criollo que sufre la discriminación por su condición de hijo de españoles nacido en tierras americanas. El relato está ambientado en Nueva Galicia, a principios del siglo XIX, y el meollo del asunto es la oposición de la madre de Rosa, bella joven de quien Eugenio está enamorado, a que su hija contraiga matrimonio con alguien que no sea español. Según Pacheco, en la época colonial "antema político y excomunión social era la suerte de la más sólida virtud y del saber más profundo si tenían la fatalidad de recaer en un hijo de español. En todas las capitales del país y hasta en los últimos cortijos, bastaba haber venido del otro lado de los mares para ser mejor que el criollo más distinguido". ${ }^{94}$

El autor deja constantes testimonios a lo largo de su obra del clima de persecución que existía contra los crio1los, según él despreciados y degradados durante la época colonial, por lo que constituye una denuncia de estos abusos y responde al clima de rechazo a lo español que ya se ha mencionado antes. Por otra parte, también existía, según Pacheco, un profundo desconocimiento del mundo, a excepción de lo concerniente a la metrópoli:

En aquellos tiempos se puede decir que en América se ignoraba la existencia del resto del mundo. Sin ninguna comunicación con el extranjero, se creía que fuera de México no había más país en la tierra que la España; y siendo aun la correspondencia con ésta muy irregular, era una cosa extraordinaria la llegada de alguna noticia de la metrópoli [...] No obstante que ya en la madre patria se batían por todas partes contra el vencedor de la Europa, incendiada toda en guerras, nada alteraba en la Nueva España, y mucho menos en la Nueva Galicia, aquella sepulcral tranquilidad todavía a fines de $1810 .{ }^{95}$

En la cita anterior encontramos nuevamente la crítica a una sociedad atrasada, sin relación con el exterior y sumida en una tranquilidad muy parecida a la muerte. 
Sin embargo, el protagonista había adquirido conocimientos superiores a los de su siglo "en el secreto estudio de las obras anatemizadas por el Santo Oficio, porque trataban de los derechos y de la historia de los pueblos". ${ }^{96}$ La relación de Rosa y Eugenio es imposible, y finalmente ella muere en sus brazos, 1o que 1leva al criollo a unirse a la lucha insurgente, y a morir fusilado:

Una tarde, en la primera de las ejecuciones que se hicieron en el costado sur de la alameda (bautismo de sangre que recibió Guadalajara de las manos del general don Félix María Calleja), venía Eugenio, más bien arrastrado que conducido, teniendo una pierna hecha pedazos. Vuelto de espalda para ser fusilado como traidor, quedaba de frente a la pared del jardín de la familia de Rosa [... Todavía existen en el muro las huellas de las [balas] que atravesaron su cabeza. Aquella noche fue espantosa en Guadalajara; mas aquella noche y otras que se le parecieron en el discurso de once años, terminaron para el Criollo con la aurora que brilló en Iguala el 24 de febrero de $1821 .{ }^{97}$

Pacheco culmina su obra nada menos que con la incorporación de su protagonista a las filas insurgentes, y su sacrificio no será en vano, ya que a partir de la promulgación de la independencia, según asegura el autor, se terminarían los problemas de los criollos. En esta novela se encuentran dos ideas imperantes en la época: el régimen colonial fue malo e injusto, y con la vida independiente, la situación había cambiado. Sin embargo, y pese al optimismo imperante, para la época en que Pacheco escribió su novela, ya se había podido dar cuenta que no necesariamente un cambio de régimen había traído el progreso deseado. De cualquier manera, resalta la idea del atraso colonial que el autor quiere dejar plasmada en su obra.

Manuel Payno, autor de Aventura de un veterano, ${ }^{98}$ también incursiona en las novelitas de tema histórico, y su obra se ubica a principios de siglo. El protagonista, Pedro Celestino Castaños, es un veterano de la guerra de Independencia que ha estado bajo las órdenes de José Ma. Morelos y dice de sí mismo: "soy un capitán insurgente, y mal que bien, mando una partida de valientes, que no dejan de dar qué hacer a las tropas del rey". ${ }^{99}$ El autor, como se puede ver, hace de su protagonista un leal soldado que
96 Ibid., p. 211.

97 Ibid., p. 248.

98 Manuel Payno, "Aventura de un veterano", en El Museo Mexicano..., t. II, pp. 481-492.

99 Ibid., p. 481. 
100 Ibid., p. 485.

101 Ibid., p. 486.

102 Ramón Isaac Alcaraz, "La condesa de Peña Aranda", en El Liceo Mexicano, t. I, pp. 237-245. lucha por conseguir la libertad de su patria. En esta novelita de Payno puede verse ya el deseo de rescatar a los héroes nacionales, lo que más adelante sería la "historia de bronce" como la 1lama Luis González. No deja de ser significativo que, en este caso, al tratarse un tema romántico, también el héroe tenga un papel especial:

En los tiempos en que se ha colocado esta narración, es decir, cuando el gran Morelos favorecido por la fortuna, había vuelto a levantar el estandarte de la libertad, era muy frecuente que así mexicanos como españoles, perseguidos simultáneamente por sus enemigos, abandonaran sus casas y parte de sus intereses. Resultaba de esto que muchas de las ricas posesiones del campo quedaban yermas y solitarias, y a la merced de las primeras tropas que querían instalarse en ellas. También en esta época había no sólo ejércitos que reunidos combatían por sus opiniones, sino guerrilleros que reunían más o menos número de hombres, y hacían la guerra por su cuenta, y cometían todo género de robos y maldades, desacreditando y entorpeciendo el progreso de la causa que defendían. ${ }^{100}$

Como se puede apreciar, en la cita anterior hay varios elementos representativos de las ideas de la época acerca de lo que fue la guerra de independencia, que significaba también la liberación; además, se ve la concepción de los ejércitos insurgentes que combatían "por sus opiniones", en contraposición a los guerrilleros que lo único que querían era sacar ventaja del desorden imperante y con esto, desprestigiar la lucha armada, que el autor describe como una pelea "por la libertad de México". ${ }^{101}$ Payno, redactor de E1 Museo Mexicano, participa del propósito nacionalista de esta publicación y trata de mostrar, a través de diversos escritos, una nación desconocida hasta entonces. Este anhelo lo plasma en su novelita de tema histórico y nacionalista: un veterano de la guerra de independencia, que lucha por la libertad de su patria.

La última novela corta de tema histórico analizada es La condesa de Peña Aranda, de Ramón Isaac Alcaraz; ${ }^{102}$ esta obra, como la de Pacheco, también está situada a principios del siglo XIX, en 1807. La crítica al régimen colonial está presente en esta narración, al igual que en las anteriores. De la sociedad colonial Alcaraz dice: 
México era la corte de una colonia: corte mezquina, reo burlesco de las cortes de los reyes, con su semi-rey y con 103 Ibid., p. 237 su farsa de nobleza. Ésta, hija de las riquezas y no de las hazañas de cien antepasados honrados y belicosos, era quizá la más ignorante y al mismo tiempo la más fatua de todas las clases de nuestra sociedad de entonces, porque muy del caso será advertir aquí que un mayorazgo, un título, el primogénito de un conde o de un marqués, con las inmensas riquezas que a la muerte del padre le quedaban, se creía dispensado de saber aun las cosas más triviales [...] ¡Sacrílega mezcla de impiedad, de religión y de orgullo! que confundidos formaban la careta que para aparecer en la sociedad nos legaron nuestros abuelos [...] Éste era en efecto el carácter distintivo de nuestra sociedad; era ésta una matrona de dos caras, de las que en una se veían las huellas profundas de la más desenfrenada prostitución, y en otra la máscara, no de la virtud, sino de la más simulada hipocresía. ${ }^{103}$

Como se ve, la opinión que tenía Alcaraz sobre la sociedad colonial no era muy halagüeña, y también él calificaba a los habitantes de la Nueva España como gente ignorante y fatua. Nuevamente se plasma en las páginas de esta obra el antihispanismo imperante en la época, y se habla de lo mucho que los mexicanos ganaron con la libertad política a raíz de la independencia. Parece que el autor quiere que sus lectores se den cuenta de que las cosas están mejor que en la época virreinal, ya que dice: "Tiempos funestos que deben convencer a los que entre nosotros suspiran por ellos todavía, de lo mucho que hemos ganado con nuestra república, con nuestra libertad, que aunque vacilantes ahora por las ambiciones particulares, jamás llegarán a caer, porque tarde o temprano el patriotismo levantará sus brazos para sostenerlas". ${ }^{104}$

El optimismo nacionalista y la visión de las bondades del sistema republicano aún prevalecían en la mente de nuestros escritores, y aunque no negaban que había problemas, éstos eran menores en comparación con lo que se había ganado al obtener la libertad. De esta idea, la obra de Alcaraz es un ejemplo fehaciente.

En los escritores de estas primeras novelas, según se ha visto, había razones de peso para tratar temas históricos, entre ellas la búsqueda de una identidad nacional; el 
105 González Acosta, op. cit., p. 79.

106 Ruedas de la Serna,

"La novela corta...", p. 71. rescate de los valores de antaño, como eran la lucha heroica por la independencia, así como el glorioso pasado indígena, y la recreación del ambiente colonial, con sus fallas e injusticias, para demostrar que el presente era mejor que los trescientos años transcurridos bajo el "yugo" español.

Estos primeros novelistas no tuvieron ningún tipo de instrucción en cuanto al oficio literario, ya que no existía la carrera de letras, y todos aprendían a escribir únicamente con la práctica, y aun así se aventuraron a tratar temas históricos que respondían a la necesidad de rescatar las glorias pasadas a partir de elementos muy convencionales. En ellos se dio el oficio de historiar pero sin el rigor de un historiador que busca en documentos del pasado la verdad de la que forma parte. Alejandro González Acosta afirma que era una exigencia del presente para los escritores decimonónicos recuperar la historia autóctona como una necesidad de "nutrir espiritualmente las nuevas naciones y fomentar el orgullo de tener patria propia". Además, durante siglos la historia se había adulterado a consecuencia del dominio español, por 1o que el objetivo primordial era clarificar la verdad de los hechos pasados mediante lo que debió ser, sin perder de vista que se trataba de obras de ficción. ${ }^{105}$

En conclusión, las novelas históricas cumplieron una función más allá de la pretensión de entretener. Hubo un trasfondo educativo en su elaboración y difusión, y la ilusión de que, por tratarse de novelitas y no de tratados históricos profundos, éstos 1legaran a un público más amplio. No se sabe si tuvieron el éxito esperado, pero el hecho es que son un legado literario de suma importancia y que, a juicio de Ruedas de la Serna, ha sido equivocadamente olvidado. ${ }^{106}$

\section{CONSIDERACIONES FINALES}

Dentro del incipiente mundo literario de las primeras décadas del siglo xix tuvieron lugar las primeras expresiones de una literatura que pretendía presentar características propias y difundir las letras nacionales. Así, durante esos años se comenzaron a dar los primeros brotes narrativos escritos por mexicanos y que tenían el fin de exal- 
tar las características del país como un lugar lleno de riqueza y con un gran futuro. Los autores de estas primeras obras de ficción, clasificadas como novelas cortas, no sólo buscaron entretener y llegar al gran público, sino que escribieron narraciones con características que pretendían plasmar una imagen de México y los mexicanos.

En lo que se refiere a la situación política y social que recrean las novelas, se ha visto que se critica a los partidos políticos y existe un sentimiento de hartazgo frente a los problemas nacionales que parecen no tener solución en el México de la época. Los primeros momentos de optimismo frente a un futuro promisorio, desembocan en fuertes críticas ante lo que se considera un estado de cosas caótico. Todos los autores, con excepción de Lacunza, Alcaraz y Pesado, hacen alusiones claras a la situación política de la época en que escriben, y critican fuertemente a los partidos políticos, los pronunciamientos, las desigualdades sociales, la corrupción imperante y, en fin, la imagen de una sociedad en formación que se enfrenta a numerosas dificultades de todo tipo, y aunque esos problemas se presentan como características nacionales, existe en nuestros autores el anhelo de que todo eso mejore y los problemas políticos desparezcan para dar paso a una era de paz.

En lo que toca a la recreación del pasado, se buscan elementos de unión como el rescate de un pasado indígena glorioso y la idea de México como una entidad que ya existía desde antes de la conquista. Por otra parte, se plasma un antihispanismo muy acorde con la época, que se refleja en las críticas constantes a la vida colonial, con su carga de injusticia y discriminación hacia todo lo que no fuera español.

En conclusión, el estudio de las primeras novelas cortas mexicanas, como ha quedado apuntado, es un recurso para conocer las costumbres, la ideología, y la mentalidad de su época; estas novelitas son una muestra de la búsqueda de identidad - a pesar del subjetivismo que ésta conlleva- y de los lazos de unión que eran necesarios en una sociedad profundamente desigual, y aunque expresión de una élite, no dejan de ser una ventana a la incipiente sociedad decimonónica, además de, como se sostiene en este análisis, una fuente no sólo literaria, sino también histórica. 


\section{BIBLIOGRAFÍA}

Fuentes primarias

Alamán, Lucas, Historia de Méjico desde los primeros movimientos que prepararon su independencia en el año de 1808 hasta la época presente. México, Imprenta de J.M. Lara, 1852.

AlCARAZ, Ramón Isaac, "La condesa de Peña Aranda", en E1 Liceo Mexicano. México, Imprenta de J. M. Lara, ca1le de la Palma núm. 4. 1844. t. I, pp. 237-245.

Arrangoiz, Francisco de Paula, México desde 1808 hasta 1867, 5a. ed. México, Porrúa, 1994. (Sepan cuántos..., núm. 82)

CAlderón, Fernando o Francisco Campero, "Mi paisano", en E1 Recreo de las Familias, [Editor: Ignacio Rodríguez Galván]. México, impreso por Mariano Arévalo, Calle de la Cadena núm. 2, Librería de Galván, 1838. pp. 371-384, 407-415.

CASTILlo, Florencio Ma. del, Obras de don Florencio M. Del Castillo. Novelas cortas. México, Imprenta de V. Agüeros, editor, Cerca de Santo Domingo núm. 4, 1902.

FERnÁndez de Lizardi, José Joaquín, E1 Periquillo Sarniento, 24a. ed. México, Porrúa, 1999. ("Sepan Cuántos..."; núm. 1).

Gómez DE LA CORTiNA, José Justo, "Sobre la colección de las mejores producciones científicas y literarias de nuestros poetas y de nuestros prosistas modernos, proyectada por Ignacio Cumplido", en "El Zurriago", E1 Siglo XIX, 2a. época, II, trim. I, 27 de mayo de 1843.

LacunZA, José María, "Netzula", en El Año Nuevo. Presente Amistoso. [Editor: Ignacio Rodríguez Galván]. México, en la librería de Galván, a cargo de Mariano Arévalo, calle de la Cadena núm. 2, t. I., 1837. pp. 15-52.

Mora, José María Luis, Obras completas. Histórica 1. México y sus revoluciones, 1. Selección, recopilación y notas de Lilian Briceño Senosiain, Laura Solares Robles y Laura Suárez de la Torre. México, SEP / Instituto de Investigaciones Doctor José María Luis Mora, 1987.

NAVARro, Juan N., "Margarita", en E1 Liceo Mexicano. México, Imprenta de J. M. Lara, calle de la Palma núm. 4, 1844, t. II, pp. 181-185 
Otero, Mariano, Ensayo sobre el verdadero estado de la cuestión social y política que se agita en la República Mexicana, 2a. ed. Guadalajara, s/e, 1952.

Pacheco, José Ramón, "El criollo", en El Año Nuevo. Presente Amistoso. [Editor: Ignacio Rodríguez Galván]. México,en la librería de Galván, a cargo de Mariano Arévalo, calle de la Cadena núm. 2, t. II, 1838. pp. 209248.

PAYNo, Manuel, "Aventura de un veterano", en El Museo Mexicano, o miscelánea pintoresca de amenidades curiosas e instructivas. Miscuit utile dulci. Horat. [Editores: Manuel Payno y Guillermo Prieto]. México, impreso y publicado por Ignacio Cumplido, calle de los Rebeldes núm. 2, 1843. T. II pp. 481-492.

PESADO, José Joaquín, "El inquisidor de México", en El Año Nuevo. Presente Amistoso. [Editor: Ignacio Rodríguez Galván]. México, en la librería de Galván, a cargo de Mariano Arévalo, calle de la Cadena núm. 2, t. I, 1838. t. II, pp. 99-137.

PRIETO, Guillermo, "Algunos desordenados apuntes que pueden considerarse cuando se escriba la historia de la bella literatura mexicana", en El Museo Mexicano o miscelánea pintoresca de amenidades curiosas e instructivas,[Editado por Manuel Payno y Guillermo Prieto]. México, impreso por Ignacio Cumplido, calle de los Rebeldes núm. 2, 1844. t. IV pp. 354-360.

-, "Manuelita", en El Siglo XIX, 2a. época, año II, núm. 338. México, 16 de mayo de 1843. pp. 2-3.

-, Memorias de mis tiempos 1828 a 1840. México, Librería de la viuda de C. Bouret, Cinco de Mayo 14, 1906.

Revilla, Domingo, "Una pasión", en El Museo Mexicano, o miscelánea pintoresca de amenidades curiosas e instructivas. Miscuit utile dulci. Horat. [Editores: Manuel Payno y Guillermo Prieto]. México, impreso y publicado por Ignacio Cumplido, calle de los Rebeldes núm. 2 , 1843. t. IV, pp. 325-337

RODRíGUEz GALVÁN, Ignacio, "Manolito el pisaverde", en E1 Año Nuevo. Presente Amistoso. [Editor: Ignacio Rodríguez Galván]. México, en la librería de Galván, a cargo de Mariano Arévalo, calle de la Cadena núm. 2, 1837, t. I, pp. 163-199. 
SARTorius, Carl Christian, México hacia 1850. México, CONACUlTA, Dirección de Publicaciones, 1990.

ZARCO, Francisco, "Discurso sobre el objeto de la literatura”, en La Ilustración Mexicana, Publicada por Ignacio Cumplido. [Editor responsable: Francisco Zarco]. México,imprenta de Ignacio Cumplido, calle de los Rebeldes núm. 2, 1851, t. I, pp. 161-168.

- , "Estado de la literatura en México", en La Ilustración Mexicana, Publicada por Ignacio Cumplido. [Editor responsable: Francisco Zarco]. México, imprenta de Ignacio Cumplido, calle de los Rebeldes núm. 2 , 1852, t. III, pp. 5-8.

- "Influencia de la prensa", en Francisco Zarco. Periodismo político y social, Boris Rosen (Comp.). México, Centro de Investigación Científica Ingeniero Jorge L. Tamayo A.C., 1989.

ZORRILLA, José, La flor de los recuerdos: ofrenda que hace a los pueblos hispanoamericanos don... México, Imprenta del Correo de España, 1855-1859.

\section{FUENTES SECUNDARIAS}

AnNA, Timothy E., Forging Mexico 1821-1835. Nebraska, Universidad de Nebraska / Lincoln y Londres, 1998.

BERLIN, Isaiah, Las raíces del romanticismo. Madrid, Taurus, 2000. (Taurus Pensamiento)

Brushwood, John S., México en su novela. México, FCE, 1998.

Florescano, Enrique, Etnia, Estado y nación. México, Aguilar, 1998.

FRANCO, Jean, Historia de la literatura hispanoamericana, 5a. ed. Barcelona, Ariel, 1975.

GELLNER, Ernest, Naciones y nacionalismo. México, Alianza Editorial, CONACUlTA, 1991. (Los Noventa, 53)

GonzÁlez Acosta, Alejandro, El enigma de Jicotencal. Estudio de dos novelas sobre el héroe de Tlaxcala. México, UNAM / Instituto Tlaxcalteca de Cultura / Gobierno del Estado de Tlaxcala, 1997.

GÓmEZ-AgUAdo DE ALBA, Guadalupe Cecilia, "El mexicano ante sí mismo. Una búsqueda de identidad a través de la novela corta. 1836-1846", tesis de licenciatura, Instituto Cultural Helénico, 2001. 
Hale, Charles A., El liberalismo mexicano en la época de Mora, 9a. ed. México, Siglo Xxi, 1991.

Jiménez RuedA, Julio, Letras mexicanas en el siglo XIX. México, Coordinación de Difusión Cultural-Dirección de Literatura-UnAm / Universidad de Colima, 1988. (Crítica Literaria 1)

MARTínez, José Luis, La expresión nacional. México, Oasis, 1984.

MATA, Óscar, La novela corta mexicana en el siglo XIX. México, UnAM, Coordinación de Humanidades, Programa Editorial, 1999. (Ida y regreso al siglo XIX)

MatuTe, Álvaro, México en el siglo XIX. Antología de fuentes e interpretaciones históricas. México, UNAM, 1992.

MirANDA CÁRABES, Celia, La novela corta en el primer romanticismo mexicano. México, CEI-IIfL-UNAM, 1985. (Nueva Biblioteca Mexicana; 96)

MuÑIZ GARCíA, Elsa, "Identidad y cultura en México", en Identidades y nacionalismos: una perspectiva interdisciplinaria, Lilia Granillo (coord.). México, UAM-Unidad Azcapotzalco,1993. (Colección Ensayos, 39)

La novela histórica y de folletín. Clásicos de la literatura mexicana, 2a. ed. México, Promexa, 1991.

Ortega y Medina, Juan A., Polémicas y ensayos mexicanos en torno a la historia, 2a. ed. México,IIH-UnAm, 1992. (Serie Documental/8)

O'GORMAn, Edmundo, "Fantasmas en la narrativa historiográfica", en Historia y Grafía. México, Universidad Iberoamericana, núm. 5, 1995.

Perales OJedA, Alicia, Asociaciones literarias mexicanas. Siglo XIX. México, CEL-UNAM, Imprenta Universitaria, 1957.

READ, J. Lloyd, The mexican historical novel. 1826-1910. Nueva York, Instituto de las Españas en los Estados Unidos, 1939.

REED TORRES, Luis y María del Carmen Ruiz Castañeda, El periodismo en México: 500 años de historia, 3a. ed. México, Edamex, 1995.

Reyes, Aurelio de los, "Manuel Payno: el aprendizaje del oficio de escritor", en Laura Beatriz Suárez de la Torre (coord.), Empresa y cultura en tinta y papel (18001860). México, Instituto de Investigaciones Dr. José Ma. Luis Mora / IIB-UNAM, Seminario de Bibliografía Mexicana del siglo XIX, 2001. pp. 638-650. 
RuEDAS DE LA SERNA, Jorge (coord.), Historiografía de la literatura mexicana. Ensayos y comentarios, Seminario de Crítica Literaria. México, FFL-UNAM, División de Estudios de Posgrado, 1996.

- La misión del escritor. Ensayos mexicanos del siglo XIX, Jorge Ruedas de la Serna (coord.), Coordinación de Humanidades-Dirección General de PublicacionesUNAM, 1996.

Ruiz Castañeda, María del Carmen y Sergio Márquez Acevedo, Diccionario de seudónimos, anagramas, iniciales y otros alias usados por escritores mexicanos y extranjeros que han publicado en México. México, IIB-UNAM, 2000.

StAPles, Anne, "Panorama educativo al comienzo de la vida independiente", en Ensayos sobre historia de la educación en México, Josefina Zoraida Vázquez, et. al. México, colmex, Centro de Estudios Históricos, 1981.

THANK DE ESTRADA, Dorothy, "La educación en la nueva nación", en Historia de México Salvat. México, Salvat, 1978., t. 9.

VAL, José del, México, identidad y nación. México, Programa Nación Multicultural-UNAM, 2004. (Colección La Pluralidad Cultural en México)

VÁZQUEZ, Josefina Zoraida, "Los primeros tropiezos", en Historia General de México. Versión 2000. México, Centro de Estudios Históricos-COLMEX, 2000. 